This item was submitted to Loughborough's Research Repository by the author.

Items in Figshare are protected by copyright, with all rights reserved, unless otherwise indicated.

\title{
Talent mobility and the shifting geographies of Latourian knowledge hubs
}

\section{PLEASE CITE THE PUBLISHED VERSION}

http://dx.doi.org/10.1002/psp.1878

\section{PUBLISHER}

(C) John Wiley and sons

\section{VERSION}

AM (Accepted Manuscript)

\section{PUBLISHER STATEMENT}

This work is made available according to the conditions of the Creative Commons Attribution-NonCommercialNoDerivatives 4.0 International (CC BY-NC-ND 4.0) licence. Full details of this licence are available at: https://creativecommons.org/licenses/by-nc-nd/4.0/

\section{LICENCE}

CC BY-NC-ND 4.0

\section{REPOSITORY RECORD}

Jons, Heike. 2014. "Talent Mobility and the Shifting Geographies of Latourian Knowledge Hubs". Loughborough University. https://hdl.handle.net/2134/16224. 
Talent mobility and the shifting geographies of Latourian knowledge hubs Heike Jöns

Please cite this paper as follows and check for updated volume number: Jons, $\mathrm{H}$ (2014) Talent mobility and the shifting geographies of Latourian knowledge hubs, Population, Space and Place, DOI: 10.1002/psp.1878

\begin{abstract}
This paper outlines how the mobility of academic talent as a significant dimension of highly skilled migration has impacted on the formation and shifting of global knowledge centres. By conceptualising talent mobility as an integral part of multifold mobilisation processes in Latourian centres of calculation, the paper aims to contribute to an ongoing development of the theoretical resources underpinning migration studies. Using Latour's concept, it examines two case studies on the global circulation of researchers and academics in the $20^{\text {th }}$ century to discuss what their insights imply for future geographies of knowledge production. The analysis shows how academic mobility from and to Europe has contributed to the emergence and reinforcement of an Anglo-American hegemony in science and higher education since the early 20th century. Based on these historical experiences, it is argued that the recent increase in transnational academic mobility from and to Asia-Pacific indicates future changes in the global geographies of knowledge production by shifting the emphasis from transatlantic to transpacific knowledge flows.
\end{abstract}

Key words transnational mobility, universities, knowledge centres, Anglo-American hegemony, Europe, Asia-Pacific 


\section{Introduction}

Geographers have made significant contributions to studying the international mobility of highly skilled professionals (e.g., Koser and Salt, 1997; Lowell and Findlay, 2001; Beaverstock, 2005; Saxenian, 2006; Harvey, 2010; Fechter and Walsh, 2012), university students (e.g., King and Ruiz-Gelices, 2003; Findlay et al., 2006; 2012; Brooks and Waters, 2011), researchers and academics (e.g., Ackers and Gill, 2008; Jöns, 2009; Leung, 2011; Heffernan and Jöns, 2013). Most of this work has shown that international students, graduates, researchers and other professionals can act as important multipliers of international relations in their subsequent careers and thus profoundly shape the global geographies of knowledge production (see also Salt, 1997; Florida, 2005; Solimano, 2008). This key finding has largely been based on qualitative research, while the literature lacks quantitative evidence about the impact of transnational circulations of skilled and talented people on global shifts of knowledge centres.

This article examines the bigger picture of how global flows of knowledge workers and centres of knowledge production are interlinked by providing a theoretically-informed and empirically-grounded longitudinal analysis of the role that circular mobility of researchers and academics has played for the formation and shifting of global knowledge nodes since the early $20^{\text {th }}$ century. The analysis aims to make two original contributions that engage with the 'ongoing theorisation and empirical richness of migration studies' (King, 2012: 148). The first original contribution suggests that talent mobility can usefully be conceptualised as an integral part of systematic mobilisation processes in what the French sociologist Bruno Latour (1987) 
called 'centres of calculation'. It thereby responds to King's (2012: 135) compelling argument that '(human) geography ... is best placed to appreciate and advance interdisciplinary thinking about migration', especially if this were based on 'intradisciplinary cross-fertilisation' (King, 2012: 148).

Latour's (1987) concept, which has been valued by historical and economic geographers (Jöns, 2011), highlights the significant role that circular movements play for generating cumulative processes of academic mobility and collaboration. The notion's intellectual origins link studies of highly skilled migration to recent conceptual debates in science studies and geography that inspired both the 'material turn' and the associated 'mobilities paradigm' (Urry, 2007). This article argues that adding ideas from science and technology studies to the great variety of concepts that have been valuable for studying the spatial dimension of populations and their movements at different geographical scales (e.g., Graham and Boyle, 2001; Legg, 2005; Findlay, 2010; King, 2012; Smith and King, 2012) helps to acknowledge the physical embodiment and spatial embeddedness of talent mobility and thus to gain a more profound understanding of long-term shifts in the geographies of knowledge production.

The second original contribution grounds conceptual debates about the role of talent mobility for the formation of knowledge centres in their specific historical geographies throughout the $20^{\text {th }}$ century. As the data for such a longitudinal study is not readily available, the analysis draws upon own archival and social scientific research from two different research projects on outgoing circular mobility from the University of Cambridge in the first half of the $20^{\text {th }}$ century and incoming circular academic mobility to the Federal Republic of Germany in the second half of the $20^{\text {th }}$ 
century. These two European perspectives were chosen for a comparison because they represent the only existing case study contexts on transnational academic mobility that allow for a longitudinal study of the whole $20^{\text {th }}$ century.

While these academic mobilities have been analysed in detail elsewhere (Jöns 2007; 2008; 2009; Heffernan and Jöns 2013), this article applies a rigorous comparative perspective to flesh out commonalities and differences in regard to the long-term impact of circular academic mobility on global knowledge nodes and their networks. It is argued that the case studies' different foci on outgoing and incoming circular mobility from a European institution and country respectively provide the required comparative perspective for achieving a more detailed conceptual and empirical understanding of how cumulative processes of academic mobility and collaboration are launched in Latourian knowledge centres and linked to shifting geographies of transnational knowledge networks. Consequently, the two case studies will help to increase our understanding of recent historical processes that brought the uneven geographies of the contemporary global knowledge economy into being and to assess what recent shifts in talent flows to Asia-Pacific may imply for future geographies of knowledge production.

\section{Mobility, centres and networks}

The term 'academic mobility' has been used for interdisciplinary studies on international movements of students and staff in higher education and research, which have proliferated since the 1990s (e.g., Altbach, 1989; Blumenthal et al., 1996; Ackers, 2005; Byram and Dervin, 2008; Welch, 2008; Fahey and Kenway, 2010). Within 
geography, international student mobility has received more attention than movements of researchers and academics, which has resulted in two distinct lines of growing research (Bauder, 2012; Waters, 2012). This article focuses on professionally motivated transnational movements of researchers and academics that range from short trips of less than a week to longer visits of up to several years and largely centre on universities but may include public and private research organisations as well. These mostly circular movements of researchers and academics are part of wider talent flows, for example, through subsequent mobility of students and researchers in the context of transnational knowledge networks (Jöns, 2009). Researchers and academics are also highly skilled professionals, who might work in different sectors of the knowledge economy during their careers.

This article examines academic mobility as a key form of 'talent mobility' because this term has the potential to work across different sectors of the knowledge economy. Talent mobility is closely linked to the more established term 'highly skilled mobility', which Lowell and Findlay (2001: 7) usefully defined as 'the movement of "tertiary" educated persons, primarily those with at least four years of education after primary and secondary school (12 years)'. In addition to advanced university graduates, talent mobility includes students in tertiary education as well as those gifted actors, athletes, artists and writers, who might not have gained certified qualifications but possess human talent and learned experience that provide them, as Solimano (2008: 1) put it, with 'an inner capacity' to develop innovative ideas, objects and performances, some of them with great economic potential. 
In this wider context of talent mobility, this article responds to four research desiderata. It attends to the need to devote more attention to transnational movements of researchers and academics (Koser and Salt, 1997; Smith and Favell, 2006); it complements a research focus on career migration between jobs (e.g., Solimano, 2008) through an examination of temporary and mostly circular movements within a job, such as academic and other business travel (Jöns, 2007; Beaverstock et al., 2010); it adds a rare quantifiable long-term perspective on the movements of scientists and scholars (Taylor et al., 2008) to prevailing qualitative accounts of talent mobility (Beaverstock, 2005, Saxenian, 2006; Ackers and Gill, 2008); and it strives to develop the conceptual basis of research on talent mobility further, as recently done and demanded by authors such as Findlay (2010), King (2012) and Smith and King (2012).

Conceptually, examinations of talent mobility have been shaped by the notion of 'brain drain', a term that was first used in 1963 by the London-based newspaper Evening Standard in response to a Royal Society report about the emigration of UK scientists to the United States and Canada in the 1950s and 1960s (Balmer et al., 2009). Initially describing asymmetric patterns of highly skilled mobility within the global North at the height of post-war Americanisation, the term was increasingly used in development contexts, where it began to imply a permanent loss of highly skilled professionals with significant negative effects for the home countries (Cervantes and Guellec, 2002). Recent globalisation processes have complicated this typical brain drain discourse through an increased volume and flexibility of global travels facilitated by the end of the Cold War and major advances in transport and communications 
technologies. This prompted the emergence of the term 'brain circulation' that was coined by a Harvard postgraduate student in 1996 as a new perspective on highly skilled mobility in the context of globalisation (Cao 1996; and personal communication with Xiaonan Cao, The World Bank, $22^{\text {nd }}$ April 2011). This new perspective captures physical and virtual, temporary and permanent movements; it accounts for the increasingly networked nature of talent migration; and it avoids a priori assumptions about causal relationships between the nature, duration and effects of talent mobility (Ackers, 2005; Jöns, 2009).

Whereas concepts such as brain drain and brain circulation help to explain geographically uneven flows of talent and the possibility of mutually beneficial relationships between home and host countries, they focus primarily on mobility at the level of regions and nation states. Recent research, however, has pointed out that institutions such as universities have always been powerful actors of knowledge production (Burke, 2000) and are increasingly so in a networked global economy (Olds, 2007). To account for the role of talent mobility in the formation of knowledge hubs below the level of nation states, Latour's (1987) notion of systematic mobilisation processes in 'centres of calculation' seems to be particularly well suited for two reasons. First, it explains conceptually how incoming and outgoing talent mobility shapes the rise, decline and shift of knowledge centres; and second, it can be applied to different geographical scales, from the individual expert, via institutions and nation states to supranational regions (Jöns, 2011).

This article therefore conceptualises centres for the production of knowledge in high tech industries, advanced producer services, universities and other research 
organisations as Latourian centres of calculation. These can be defined as venues in which knowledge production builds upon the systematic accumulation of heterogeneous resources through repeated circulatory movements to other places (Figure 1a). Adopting an historical perspective, Latour (1987: 225) argued that from the ages of discovery and exploration onwards, the recurring mobilisation of drawings, maps, images, information, stones, plants, animals and other specimen from distant places in European museums, archives, universities and laboratories has shaped the cumulative nature of the sciences and established Europe as the global centre of the imperial age. Latour (1987) explained why expeditions that neither returned nor fed any new information and material resources back home had no positive impact on the point of departure (Figure 1a-i), while each full circuit of mobilisation, such as Christopher Columbus' journey to the Americas in the late $15^{\text {th }}$ century, added to the accumulation of heterogeneous resources in the centre, thus providing an opportunity for the production of new knowledge about far-flung places and phenomena that made these accessible from a distance and thereby controllable (Figure 1a-ii/iii).

Such mobilisation processes, whether based on human travel or correspondence networks, have relied heavily on what Latour (1987: 227) characterised as 'immutable and combinable mobiles'. These include a variety of animate and inanimate non-human entities, or sociomaterial inscriptions, 'that can be mobilised, gathered, archived, coded, recalculated and displayed' (Ibid.) and thereby transformed into powerful classifications and taxonomies that represent coherent and well-communicable knowledge claims about much more complex phenomena. In this understanding, knowledge production requires scientists and scholars to engage with 
three processes that Latour (1987) regards as being constitutive of centres of calculation: the mobilisation of human and non-human resources through own and other people's travels and correspondence networks; the stabilisation of new knowledge claims through work of systematisation, classification, transformation and abstraction (often within centres of calculation); and the validation, dissemination and preservation of new knowledge and its products in different contexts than the original place(s) of construction.

Whereas the degree of immutability of 'immutable' mobiles is contested (Law, 2002), the distribution of agency to networks of human and non-human 'actants' explains the material foundations of an actor-network theoretical approach to knowledge production because according to Latour (1987: 237), 'the logistics of immutable mobiles is what we have to admire and study, not the seemingly miraculous supplement of force gained by scientists thinking hard in their offices'. The spatial reach and changing configurations of mobilisation processes in centres of calculation can thus be reconstructed, as done in this article, by tracing the travels of researchers and academics but such a focus needs to consider that these travels are constituted by complex interactions between human and non-human resources (Livingstone, 2003).

[Figure 1 about here]

From the perspective of travelling scientists and scholars, their mobilisation processes may not only be beneficial for their home university but also for those 
people and places they encounter during their travels, especially if they spend longer periods of time at a host institution, where their interactions provide the basis for continuing transnational knowledge networks (Jöns, 2009). Circular mobility between two centres of knowledge can therefore be interpreted as a twofold mobilisation process, involving at least the point of departure and the place of destination (Figure 1b-ii). In extension of Latour's (1987) concept, a potentially twofold cumulative effect can also be identified for reciprocal movements, when researchers shuttle between two or more workplaces (Figure $1 \mathrm{~b}-\mathrm{i}$ ). In the case of linear moves from one workplace to another, the researcher's resources will be lost at the former home base but beneficial networks may still be maintained (Figure $1 \mathrm{~b}$-iii). Mobilisation processes through talent mobility may even become multifold if they involve either more than one home or host institution (Figure 1c-ii) or a number of subsequent destinations (Figure 1c-i) that may in some cases even lead to a return move (Figure 1c-iii). Different trajectories of corporeal mobility in the form of circular, reciprocal, linear and return moves, as outlined in similar ways by King and Skeldon (2010: 1622) in their integrated conceptualisation of internal and international migration, thus add to accumulation processes in knowledge centres, albeit in very different ways. In a relational understanding, the actual effects also vary by empirical context, but all trajectories are linked to Urry's (2007: 47) five inter-dependent forms of mobilities, which have the potential to generate brain circulation by connecting knowledge centres through corporeal, imaginative, communicative and virtual travel as well as the movement of material objects. The concept of mobilisation processes in centres of calculation therefore connects knowledge centres and circulations, places and flows, 
collective mobility and networks and explains how especially circular travels have the potential to reinforce the central status of individuals, institutions, places, regions and states if the acquired material (e.g., specimen), intellectual (e.g., ideas) and social resources (e.g., collaborators) are successfully used for the creation of new knowledge and academic networks.

Conceptualising centres of knowledge production, or knowledge nodes and hubs, as Latourian centres of calculation, also supports the argument that cumulative effects of recurrent talent mobility, whether incoming, outgoing or both, indicate dynamic processes with potential future significance for the economic, social and cultural prosperity of a knowledge centre. The presence of international researchers and academics can not only be expected to create and reinforce the central status of knowledge hubs because of the knowledge, expertise and academic contacts these visitors bring to their host institution but also because of their potential contribution to enriching the cultural, intellectual and public life of wider society (Sadlak and Liu, 2007). Even if not all instances of academic mobility might generate wider benefits or can be interpreted as a sign of academic 'excellence' (Ackers, 2008), the employed conceptual framework underlines that mapping changes in collective flows of academic and other talent, including students as imminent skilled professionals, points to future shifts in central knowledge nodes and networks, particularly if these go handin-hand with major transformations in the world economy. 


\section{Research methodology and data sources}

Methodologically, the conceptual considerations underline that both institutional and national perspectives as well as the study of incoming and outgoing mobility all present valid strategies for accessing the global flows of talent. Accordingly, this article studies the formation of global knowledge centres through academic mobility from two European perspectives: outgoing mobility from the University of Cambridge as an institutional centre of calculation in the first half of the $20^{\text {th }}$ century; and incoming mobility to several host institutions in the Federal Republic of Germany during its second half. It is argued that weaving the findings of these two research projects into a longitudinal narrative about shifting knowledge centres provides a unique opportunity for explaining present configurations of the global knowledge economy through past mobilities and to use these insights for understanding potential future developments based on recent changes in international flows of students and researchers.

The research about academic travel from the University of Cambridge is based on archival records on all applications for leave of absence by Cambridge academics from 1885 to 1955. Based on the entries in the Minute books of the General Board of Studies (since 1926 the General Board of the Faculties), a database was created with information on the applicant, on the period of absence, its purpose, the planned destinations and whether the leave was granted, which was almost always the case. Absences of more than three months were best covered for two reasons. First, they exceeded the duration of the summer vacation and thus required leave of absence for those parts of term that were missed; and second, they included regular research sabbaticals that were introduced in Cambridge in 1926 (Jöns, 2008). 
The case study on academic mobility to Germany focuses on research visits of international scientists and scholars funded by the Alexander von Humboldt Foundation in the Federal Republic of Germany from 1954 to 2001. This project used a multi-method approach, combining data provided by the Humboldt Foundation, a comprehensive postal survey and face-to-face interviews with former Humboldt research fellows from all disciplines and source countries. The analysis thus draws on data about all 17,216 former visiting researchers in the period 1954 to $2001 ; 1,893$ questionnaires from a sample survey of every fifth of them (response rate 51\%); and 21 face-to-face interviews (Jöns, 2009).

Due to the comparative and longitudinal perspective, this study prioritises the interpretation of collective mobility patterns and experiences. While the two European research perspectives need to be situated in their specific temporal and spatial contexts, it is argued that in comparison they help to outline main trends in transnational academic mobility during the $20^{\text {th }}$ century. The following analysis aims to answer three research questions: Which circumstances launched cumulative processes of academic mobility and collaboration in Latourian knowledge centres? What were the geographical and disciplinary patterns of such cumulative processes and how did they shape the global geographies of knowledge production? What do the historical case studies suggest in regard to the impact that shifting talent flows to Asia-Pacific may have on global knowledge centres and their networks in the future? 


\section{The rise of Anglo-American hegemony}

At the beginning of the $20^{\text {th }}$ century, the University of Cambridge hosted a largely sedentary academic community (Figure 2a). Research travel occurred largely outside of the university, either in the form of scientific exploration, which continued the late $18^{\text {th }}$ century tradition of James Cook's voyages into the Pacific and was funded by institutions such as the Royal Geographical Society, or as educational travel that was modelled on the Grand Tour through the cultural centres of Europe and had become increasingly accessible to the more affluent parts of the middle classes (Simões et al., 2003; Heffernan and Jöns, 2013). In order to understand how research travel was introduced into the University of Cambridge, it is necessary to consider academic mobilities between universities in Germany and the United States as the subsequent academic hegemons in the $19^{\text {th }}$ and $20^{\text {th }}$ centuries.

In the second half of the $19^{\text {th }}$ century, German universities experienced a large influx of international students, especially from the United States (Honeck and Meusburger, 2012). Based on the concept of the research university, which was first implemented by Wilhelm von Humboldt with the foundation of Berlin University in 1810, German universities provided doctoral research training that became only gradually available in other countries (Clark, 2006). Many Americans, who studied or received their doctorates at German universities, were instrumental in reforming US universities along German lines, which began to reduce the need to study in Germany and thus weakened academic flows between the two countries as well as the Germanlanguage orientation among American academics from the 1890s onwards (Honeck and Meusburger, 2012). The advent of the research university in the United States can 
thus be interpreted as a crucial outcome of systematic mobilisation processes in emerging hegemonic centres of calculation, which contributed to a gradual shift of power-relations from German to US universities.

A major innovation at the new American research universities was the introduction of the first known system of sabbatical leave at Harvard University in 1880 (Eells, 1962). This concept, which was subsequently implemented at other US research universities, provided its academics with periods of uninterrupted research by freeing them at regular intervals from their duties in teaching and administration. On the one hand, this enabled US academics to travel to Europe and especially to German universities that epitomised the pinnacle of science and scholarship in the late $19^{\text {th }}$ and early $20^{\text {th }}$ century; on the other hand, this generated the need to fill vacant positions of professors on sabbatical leave with visiting appointments. In this context, the first professorial exchange programmes worldwide emerged between the University of Berlin and the two main American east coast universities, Columbia and Harvard, in 1905 (vom Brocke, 1981). Similar agreements between these two US universities and the Parisian Sorbonne followed in 1909 (Charle, 2004).

As a reflection of a climate of European rivalry at the end of the $19^{\text {th }}$ century up to WWI, academic exchanges between Germany, France and Britain were rare, whereas interactions with the United States began to flourish in all three countries and encouraged the development of strong transatlantic knowledge networks (Charle, 2004; Jöns, 2008; Taylor et al., 2008). The increasing attraction of US research universities was also a major stimulus for comprehensive university reforms in the ancient British universities of Oxford and Cambridge that had long opposed the 
German innovation of the research university and largely served as finishing schools for the clergy and for civil servants with imperial ambitions (Brooke, 1993). The second of three major reforms at the University of Cambridge introduced regulations for travel so that from 1885 onwards, professors and readers had to be resident in Cambridge throughout full term time to be accessible for their students and colleagues. They were obliged to apply for leave of absence from the university if they stayed away from Cambridge throughout full term time for more than two nights (Heffernan and Jöns, 2013).

The resulting records show that overseas research travel from Cambridge begun to flourish only in the 1920s, after the university had introduced a system of research sabbaticals in 1926 (Figure 2a). The effects of this reform were interrupted by WWII, when a large number of Cambridge academics entered war service, but the wider trend towards more overseas travel, especially for research-related inquiries, continued in the 1940 s and 1950 s due to improved transportation, an expanding body of academics, and the fact that travel had become the key research technique (Heffernan and Jöns, 2013). It can be argued that the University of Cambridge launched its own mobilisation processes by following the example of the increasingly visible US research universities and providing academics across all disciplines with the opportunity to travel for research at regular intervals because the increased volume of research travel guaranteed those important accumulation processes that circular movements generate in Latourian centres of calculation.

[Figure 2 about here] 
The path dependency of an emphasis on research through regular study leave and academic travel is underlined by the intriguing coincidence that Harvard University, the first institution worldwide that is known to have established a system of sabbatical leave (in 1880), has been heading the annually published Shanghai world university ranking, which measures research performance with indicators going back to the early $20^{\text {th }}$ century, in all years since its inception in 2003, whereas Cambridge, which is most likely the first European university that has introduced regular research leaves (in 1926 and thus 28 years earlier than Oxford), has consistently been listed as the leading European research university (ShanghaiRanking Consultancy, 2013).

The geographies of knowledge production in the University of Cambridge became increasingly global from 1901 to 1955, when almost three fourth of all granted academic leaves involved travelling abroad (73\%). The geopolitical configurations of the British Empire shaped the geographies of academic travel especially in the 1910s and 1920s (Figure 2b) and were therefore of similar relevance for academic knowledge production as for professorial appointment practices in British and imperial universities at the time (Pietsch, 2010). In subsequent decades, imminent decolonisation of many British territories as well as an increasing Americanisation and Europeanisation of academic travel went hand-in-hand with declining shares of destinations within the British Empire (Figure 2b).

The most significant trend was a disproportionate rise of academic travel from Cambridge to the United States, which had been the most popular destination since the 1900s. Initially, the main reasons for travel were invited lectures and conferences at US universities (Figure 4) but after the introduction of sabbatical leave in 1926, 
visiting appointments and research became the dominant reasons for travelling to the United States (Figure 3). In conceptual terms, it is therefore evident that academic travel from the University of Cambridge was originally encouraged by a demand for established European expertise in the new US research universities and thus by mobilisation processes on the initiative of the emerging academic hegemon. Only the introduction of the sabbatical scheme marked the beginning of Cambridge's own systematic mobilisation processes for research that eventually transformed this institution into a modern research university.

The United States' material superiority led to a growing attractiveness of new research laboratories and libraries, potential collaborators and innovative research themes in the world's rising hegemonic power, particularly for natural, technical and social scientists (vom Brocke, 1981; Charle, 2004; Heffernan and Jöns, 2013). At the height of American hegemony between 1946 and 1955, 40\% of all overseas academic travel from Cambridge was directed to the United States. This twofold mobilisation process was crucial for the development of close academic ties between British and US universities that proliferated on the basis of a common English language, supported the rise of US universities to worldwide leading scientific centres, and gave rise to an Anglo-American hegemony in science and higher education (Figures 3 and 4).

[Figure 3 about here - full page]

[Figure 4 about here - full page] 
The global geographies of academic travel from Cambridge varied substantially between different types of academic work. Destinations for research-based activities such as research/travelling (31\%) and advisory work (10\%) were geographically dispersed because academics were able to mobilise new resources for their work in a variety of geographical contexts, thereby making their university a classical centre of calculation (Figure 3). In contrast, destinations for dissemination-based activities, such as lecturing (21\%) and conference visits (24\%), were geographically concentrated in existing knowledge centres, especially in Europe and the United States (Figure 4). Based on the worldwide displacement and accumulation of knowledge resources in Cambridge through research and the intellectually and socially important discussion of new findings in existing knowledge hubs, academic travel deepened uneven global geographies between Britain and its (former) colonies as well as between a wellintegrated global North and a resource-intensive but academically largely disconnected global South (Jöns, 2008).

Conceptually, this demonstrates a difference in the impact of academic travel on culturally transformed destinations, to which academic resources and networks - or different forms of economic, cultural, social and symbolic capital (Bourdieu, 1986) have previously been extended, and largely untransformed field sites. The former may benefit more from cultural encounter and exchange because academic hosts can learn from the visitors (and vice versa), collaborate and establish academic networks. This would not be possible in places that lack such investment in academic infrastructure and thus explains why academic travel tends to reinforce asymmetric power-relations. 
Prior to the 1920s, overseas academic travel from Cambridge was most frequent in the social sciences and humanities but the natural sciences dominated from the 1920 s onwards (Figure 2c). This change in the disciplinary profile resulted from a higher demand for travel in the physical and biological sciences, especially for knowledge exchange at conferences, and shaped all travel cultures 'by making them more targeted and output-oriented' (Heffernan and Jöns, 2013: 285). While academic travel in almost all disciplines and types of work contributed to an Anglo-American academic hegemony, this development was increasingly driven by the expensive laboratory sciences. No less than $51 \%$ of overseas laboratory research focused on the United States, whereas $39 \%$ of scientific fieldwork and only $13 \%$ of laboratory work targeted imperial destinations (1901-55; share of fieldwork in the United States: 9\%).

This shows how the types of human and non-human resources constitutive of various research practices shape the geographies of academic travel in very different ways. More mobile 'immutable' mobiles can easily be brought back home from a range of destinations (e.g. soil samples), whereas immobile resources such as large experimental facilities are more confined to specific places because they need to be accessed frequently and require previous investment. As exemplified by the techno sciences that underpinned US hegemony, accumulation processes have been most powerful in those laboratory sciences, in which the place of knowledge production and the site of study merged in an economically prosperous location. 


\section{Connecting West and East}

The Second World War interrupted research and teaching in most European universities and had particularly devastating effects for West and East German universities, where in addition to the physical destruction of buildings and infrastructure, the Nazi regime had deprived the once renowned institutions of more than half of their academic staff (Krohn et al., 1998). After the war, efforts of rebuilding West German higher education included the re-establishment of academic exchange programmes conducted by institutions such as the German Academic Exchange Service (DAAD) and the Alexander von Humboldt Foundation (AvH), the former focussing on the support of international students and the latter on funding international researchers and academics.

The basic idea of the Humboldt research fellowship programme, which began in 1954, was to invite foreign researchers from all countries and disciplines for a period of research to the Federal Republic of Germany (Jansen, 2004) and therefore to reconnect with the international scientific community via incoming circular academic mobility. From 1954 to 2000 , this programme funded the research leaves of 16,669 visiting scientists and scholars from 131 countries with an average age of 35 years, of whom about $80 \%$ were based at universities and $20 \%$ at Max Planck Institutes and other research organisations (Jöns, 2003).

The number of both applications and fellowships rose steadily from the $1950 \mathrm{~s}$ to the 1990s, which reflects an increasing international academic interest governed by the reintegration of West Germany into the international scientific community, the considerable expansion of West German higher education and research in the 1960s 
and 1970s, and a significant improvement of research infrastructure and quality, especially in the 1980s (Weingart, 1998). The fall of the Iron Curtain led to a temporary boom in applications, especially from Russia and Eastern European countries, but it also resulted in growing opportunities for mobility that together with the recent growth of Chinese science has enhanced international competition for visiting researchers and thus consolidated applications in the 2000s on the level of the 1980s (Figure 5a).

[Figure 5 about here]

Initially, most visiting researchers came from developing countries (e.g., India, Argentina), former war allies (e.g., Japan), and less affluent nations in the Mediterranean (e.g., Greece, Turkey). The number of visiting researchers from the United States rose steadily from the 1950 s to the 1970 s but included mainly scholars in the humanities and social sciences because their required research infrastructure had mostly survived in libraries and archives or was accessible in the empirical context of everyday life. By the 1970s, considerable public investment in scientific research had helped to build up internationally attractive research facilities, which enabled West German universities to attract an increasing number of natural and technical scientists from North America, the UK, France and Australia (Figure 6). The first visiting researchers from territories of the former Soviet Union arrived in 1970 and from China in 1979, but their numbers increased so much in the 1990 s and for China also in the 2000s that Asia has become the most important region of origin (Figure 5b). 
[Figure 6 about here]

In similar ways as in Cambridge during the first half of the $20^{\text {th }}$ century, the disciplinary profile of Humboldt research fellows shifted from a relatively high share of the humanities and social sciences in the 1950s and 1960s to a clear dominance of the natural and technical sciences from the 1970s onwards (Figure 5c). This can be explained by the rebuilding of scientific infrastructure and the ever greater economic role that the natural and technical sciences played in society, especially during the Cold War, when these subjects began to dominate university budgets, publication outputs and international collaborations (Paasi, 2005).

The most significant outcome of the Humboldt research fellowship programme was subsequent mobility. Almost $90 \%$ of the Humboldt research leaves from 1954 to 2000 generated subsequent mobility of students, researchers and academics: $86 \%$ from abroad to Germany, $58 \%$ from Germany to abroad, and no less than $56 \%$ in both directions. Many of these subsequent research visits lasted over one month, the most important link being provided by return visits of Humboldt research fellows. From the 1950 s to the 1980 s, this pattern was surprisingly stable and only varied in the 1990s because less time had passed when the survey was conducted, but due to the more than fivefold rise in the number of Humboldt research fellows by the 1980s, this meant that more and more students and researchers at different career stages came to Germany and went abroad (Jöns, 2009).

In line with the notion of a twofold mobilisation process in the home and host institutions (Figure 1b-ii), the case study on visiting researchers in Germany thus shows 
that the Humboldt programmes and similar funding schemes for circular academic mobility have launched and maintained cumulative processes of subsequent academic mobility and collaboration that contributed significantly to the internationalisation of higher education and research in this country. Moreover, Jöns (2009) argued that the resulting brain circulation allowed Germany to become the most important source country for international co-authors of journal articles written by US scientists and engineers in the period 2001 to 2005 (13.1\%), ahead of the UK (12.9\%) and Canada (11.6\%; China: 6.1\%; Adams et al., 2007: 13). Visiting scientists and engineers from the United States mostly interacted with doctoral students and post-docs in Germany, whom they then invited to their home institution for two to three years of postdoctoral research. Many of these postdocs subsequently became professors in Germany, who maintained transatlantic collaborations and exchanges, including the publication of joint articles, which explains the close link between circular academic mobility and transnational knowledge networks as expressed by international patterns of co-authorship.

The conceptual idea that cycles of mobilisation in Latourian centres of calculation generate cumulative effects that contribute to the rise of knowledge hubs has thus clearly been verified by the Humboldt schemes for circular academic mobility and the prominence of Germany-based scientists in international collaborations with US colleagues. In the first four post-war decades, these cumulative processes of academic mobility and collaboration mainly reinforced Anglo-American hegemonic relations, but since the 1990s the geographical emphasis has shifted towards China, India and Russia, mainly due to the end of the Cold War, the growth of Chinese 
science, and the financial attractiveness of Humboldt research fellowships for Asian researchers (Leydesdorff and Wagner, 2009; Leung 2011; 2013).

\section{From transatlantic to transpacific mobilities}

The ongoing reorientation of global flows of talent, which has widely been discussed in recent academic literature (e.g., Saxenian, 2006; Zweig et al., 2008; Altbach, 2010; OECD, 2013), is particularly evident in the Humboldt research fellowship programme. Over the past three decades, the shares of the visiting researchers' source countries changed from 13\% United States and 5\% China (1981-1990) via 10\% United States and 12\% China (1991-2000) to 12\% United States and 16\% China (2001-2010). Rapidly accelerating mobilisation processes through outgoing academic mobility from China are also evident in international student mobility to the United States because the share of Chinese students has almost tripled from $10 \%$ in $2000 / 01$ to $29 \%$ in $2012 / 13$ (IIE, 2013).

This article argues that the ongoing shift in emphasis of global talent flows from established scientific nations such as the United States to emerging economies in AsiaPacific has launched similar cumulative processes of academic mobility and collaboration as this article has outlined for Anglo-American academic relations in the first half of the $20^{\text {th }}$ century and for German-American relations in the second half of the $20^{\text {th }}$ century. This argument is supported by the observation that the reorientation of global talent flows has already impacted so much on international co-authorship patterns in scientific research that China was the most important source country for 
international co-authors of documents published by US-based scientists and engineers in 2011, thus leaving the UK, Germany and Canada behind (OECD, 2013: 59).

Interestingly, the wider shift of global flows of students, researchers and academics from and to Asia-Pacific is being reinforced by changing diasporic networks. In the first four post-war decades, family linkages to Europe served as an important additional stimulus for US scientists and scholars to spend their sabbatical year in West Germany and subsequently to create lasting knowledge networks (Jöns et al., 2014). However, for historical reasons, the number of German- and other European-born researchers in the United States has been on the decrease for some time, while more and more US researchers have an Asian family background. For example, in engineering at US colleges and universities $27 \%$ of full-time faculty and $58 \%$ of postdocs were Asian in 2010 (NSB 2014, Appendix Table 5-16). These shares can be expected to increase further because over $60 \%$ of all international students in the United States during the academic year 2012/13 came from Asia (IIE, 2013). China is the top sending country for foreign students in the United States (29\% in 2012/13; IIE, 2013), and many of these will stay on in the country (Hazen and Alberts, 2006), thus constituting a growing Chinese knowledge diaspora. Most of these US-based Chinese academics maintain close scientific interactions with the mainland (Zweig et al., 2008) and spend at least one sabbatical back home, close to family, friends and long-term collaborators. The changing diasporic networks at US research universities will therefore impact on the future recruitment of visiting researchers from the United States by putting Asia in a more favourable situation than Europe (Yang and Welch, 2010). 
Based on the conceptual insights on mobilisation processes in Latourian centres of calculation and the discussed empirical case studies, there are thus good reasons to assume that the cumulative processes of academic mobility and collaboration that have intensified in China since the 1990s (Zweig et al., 2008) will most likely, if no major geopolitical conflicts will emerge, reinforce the centrality of Chinese and other Asian-Pacific knowledge hubs over the coming decades and potentially also create a challenge to Anglo-American academic hegemony in the not too distant future. Given that the United States are still the worldwide leading scientific nation and that China is rapidly catching up with research efforts at US universities (OECD, 2013), this also means that European universities need to make sure that they remain well-integrated into intensifying transpacific knowledge networks.

\section{Conclusions}

This article has examined circular academic mobility of researchers and academics from two European perspectives over a period of more than a century with the twofold aim of advancing conceptual debates on talent mobility and providing a longitudinal comparative perspective on the relationship between academic mobility and changing geographies of knowledge centres. The analysis contributes four main findings to vital debates about talent mobility.

First, the longitudinal perspective has revealed how intensifying circular flows of researchers and academics initiated global shifts in knowledge centres and their networks. Conceptualising talent mobility as multifold mobilisation processes in Latourian centres of knowledge production has especially helped to explain how 
increased academic mobility contributed to the rise of American, British, German and most recently Chinese universities to important global knowledge hubs. Intensifying academic travel from the University of Cambridge to the United States from the 1900s to the 1950 s also contributed to the rise of an Anglo-American academic hegemony, whereas academic mobility to the Federal Republic of Germany from the 1950s onwards fostered the westernisation of West German universities and has more recently seen an intensification of exchanges with China, India and Russia.

Second, the analysis has shown that the disciplinary profiles of academic travellers from Cambridge in the first half of the $20^{\text {th }}$ century and to Germany in the second half of the $20^{\text {th }}$ century underwent gradual long-term changes from an initial emphasis on the humanities to a focus on the more resource-intensive natural and technical sciences. The main difference to the building up of Chinese university-based knowledge centres in the $21^{\text {st }}$ century is the absence of such a transition from the humanities to the sciences because the profile of mobile academics from and to China has been dominated by the natural and technical sciences since the 1970s (Jöns, 2003; Leung, 2013). This can be explained by the ambition of Chinese universities to emulate the success story of the US techno scientific complex because this represents key institutions in the world economy's most recent hegemonic centre, which according to Taylor (1996) has historically been an important practice of rising hegemonic rivals.

Third, based on the historical case studies, this article has argued that the most recent shift of academic flows towards Asia-Pacific indicates changes in worldwide accumulation processes with important consequences for future configurations of global knowledge centres and their networks. Comparing long-term hegemonic shifts 
in the European economy from the $16^{\text {th }}$ to the $19^{\text {th }}$ century with geographical configurations of knowledge centres shows that economic development either preceded or went hand-in-hand with growing academic mobility because enormous investment was required for creating attractive contexts for learning, teaching and research (Taylor et al., 2008). In this article, the case study on Cambridge underlined a growing attractiveness of US universities during the rise and height of American hegemony, while recent increases in the global circulation of international students and researchers from and to China have followed a wider economic shift towards AsiaPacific (Saxenian, 2006; Jöns and Hoyler, 2013).

Fourth, this study has shown that institutionalised funding schemes were pivotal for launching cumulative processes of academic mobility and collaboration. In Cambridge, the university encouraged academic travel in all disciplines through the provision of regular research sabbaticals from 1926 onwards. In Germany, the postwar Humboldt Foundation became part of a sophisticated system of foreign cultural policy institutions that have offered an increasingly differentiated portfolio of funding schemes for incoming and outgoing academic mobility. While this system has evolved over more than six decades, its success suggests that it can serve as a role model for other European countries that, in the light of shifting global flows of talent, might not much longer be able to take the inflow of externally-funded international students and researchers for granted and therefore need to stimulate cumulative processes of mobility and collaboration in other ways to counter shifting alliances from transatlantic to transpacific knowledge flows. 
In conclusion, it is argued that institutions and countries with a developed sabbatical culture such as the UK need to complement this competitive advantage with differentiated fellowship schemes, whereas countries with solid public and/or private support for academic mobility such as Germany need to encourage their universities to develop a sabbatical culture in order to remain competitive in the future. Interestingly, both of these long-term assets have characterised American higher education and research since the late $19^{\text {th }}$ century, which is exemplified by the early sabbatical culture and the provision of mobility schemes by institutions such as the National Science Foundation, the Rockefeller Foundation and the Fulbright Commission (Parmar, 2002). The combination of a differentiated portfolio of privately and publiclyfunded schemes for incoming and outgoing transnational academic mobility and a well-developed sabbatical culture thus seems to sketch a sustainable future for central and well-networked global knowledge hubs in Europe and elsewhere. 


\section{Acknowledgements}

This article is based on research funded by the German Research Foundation (DFG project ME 807/18-1) and the Alexander von Humboldt Foundation (jointly with the University of Nottingham). I gratefully acknowledge valuable discussions on earlier versions at the Universities of Kiel and Bremen; at the Joint Royal Society - Alexander von Humboldt Foundation Meeting in the Royal Society, London; and at the Academia Europaea Conference on Migration and Mobility in Science in the Accademia Nazionale dei Lincei, Rome. My sincere thanks go to Mike Heffernan, Peter Meusburger, Tim Freytag, Anne Buttimer, Darren Smith, the editor Allan Findlay and two anonymous referees for their constructive feedback on producing this final version. The views expressed in this article and any errors are solely my responsibility. 


\section{References}

Ackers L. 2005. Moving people and knowledge: scientific mobility in the European Union. International Migration 43: 99-131.

Ackers L. 2008. Internationalisation, mobility and metrics: a new form of indirect discrimination? Minerva 46: 411-435.

Ackers L, Gill B. 2008. Moving People and Knowledge: Scientific Mobility in an Enlarging European Union. Edward Elgar: Cheltenham.

Adams J, Gurney K, Marshall S. 2007. Patterns of International Collaboration for the UK and Leading Partners. Evidence Ltd.: Leeds.

Altbach PG. 1989. The new internationalism: foreign students and scholars. Studies in Higher Education 14: 125-136.

Altbach PG. 2010. The Asian higher education century? International Higher Education 59: $3-5$.

Balmer B, Godwin M, Gregory J. 2009. The Royal Society and the 'brain drain': natural scientists meet social science. Notes \& Records of the Royal Society 63: 339-353.

Bauder H. 2012. The international mobility of academics: a labour market perspective. International Migration. DOI: 10.1111/j.1468-2435.2012.00783.x

Beaverstock JV. 2005. Transnational elites in the city: British highly-skilled intercompany transferees in New York City's financial district. Journal of Ethnic and Migration Studies 31: 245-268.

Beaverstock JV, Derudder B, Faulconbridge J, Witlox F (eds.). 2010. International Business Travel in the Global Economy. Ashgate Publishing: Farnham. 
Blumenthal, P, Goodwin CD, Smith A, Teichler U (eds.). (1996) Academic mobility in a changing world, London: Jessica Kingsley Publishers.

Bourdieu P. 1986. The forms of capital. In Handbook of Theory and Research for the Sociology of Education, Richardson JG (ed.); Greenwood Publishing Group: New York; 241-258.

Brooke CNL. 1993. A History of the University of Cambridge, vol. 4: 1870-1990. Cambridge University Press: Cambridge.

Brooks R, Waters J. 2011. Student Mobilities, Migration and the Internationalization of Higher Education. Palgrave Macmillan: Basingstoke.

Burke P. 2000. A Social History of Knowledge. Polity Press: Cambridge.

Byram M, Dervin F (eds.). 2008. Students, Staff and Academic Mobility in Higher Education. Cambridge Scholars Publishing: Newcastle.

Cao X. 1996. Debating 'brain drain' in the context of globalisation. Compare: A Journal of Comparative and International Education 26: 269-285.

Cervantes M, Guellec D. 2002. The brain drain: old myths, new realities. OECD Observer 230: 40-42.

Charle C. 2004. The intellectual networks of two leading universities: Paris and Berlin, 1890-1930. In Transnational Intellectual Networks, Charle C, Schriewer J, Wagner P (eds.); Campus: Frankfurt; 401-450.

Clark W. 2006. Academic Charisma and the Origins of the Research University. University of Chicago Press: Chicago.

Eells WC. 1962. The origin and early history of sabbatical leave. Bulletin, American Association of University Professors 48: 253-256. 
Fahey J, Kenway J. 2010. International academic mobility: problematic and possible paradigms. Discourse: Studies in the Cultural Politics of Education 31: 563-575. Fechter A-M, Walsh K (eds.). 2012. The New Expatriates: Postcolonial Approaches to Mobile Professionals. Routledge: London.

Findlay AM. 2010. An assessment of supply and demand-side theorizations of international student migration. International Migration 49: 162-190.

Findlay A, King R, Stam A, Ruiz-Gelices E. 2006. Ever reluctant Europeans: the changing geographies of UK students studying and working abroad. European Urban and Regional Studies 13: 291-318.

Findlay A, King R, Smith FM, Geddes A, Skeldon R. 2012. World class? An investigation of globalisation, difference and international student mobility. Transactions of the Institute of British Geographers 37: 118-131.

Florida R. 2005. The Flight of the Creative Class: The New Global Competition for Talent. Harper Collins: New York.

Graham E, Boyle P. 2001. (Re)theorising population geography: mapping the unfamiliar. Population, Space and Place 18: 209-224.

Harvey W. 2010 British and Indian scientists moving to the United States. Work and Occupations 38: 68-100.

Hazen HD, Alberts HC. 2006. Visitors or immigrants? International students in the United States. Population, Space and Place 12: 201-216.

Heffernan M, Jöns H. 2013. Research travel and disciplinary identities in the University of Cambridge, 1885-1955. The British Journal for the History of Science 46: 255286. 
Honeck M, Meusburger P. 2012. American students up to 1914. In Wissenschaftsatlas of Heidelberg University. Meusburger P, Schuch T (eds.); Bibliotheca Palatina: Knittlingen; 296-299.

IIE (ed.). 2013. Open Doors Report on International Educational Exchange. Institute of International Education: New York. http://www.iie.org/opendoors (accessed $12^{\text {th }}$ July 2014).

Jansen C. 2004. Exzellenz weltweit: die Alexander von Humboldt-Stiftung zwischen Wissenschaftsförderung und auswärtiger Kulturpolitik (1953-2003), unter Mitarbeit von Christoph Nensa, Cologne: Dumont.

Jöns H. 2003. Geographies of international scientific exchange in their political context. In Frontiers of Geography, Nemes Nagy J, Jakobi A (eds.); Department of Regional Geography, ELTE: Budapest; 227-247.

Jöns H. 2007. Transnational mobility and the spaces of knowledge production: a comparison of global patterns, motivations and collaborations in different academic fields. Social Geography 2: 97-114.

Jöns H. 2008. Academic travel from Cambridge University and the formation of centres of knowledge, 1885-1954. Journal of Historical Geography 34: 338- 362.

Jöns H. 2009. 'Brain circulation' and transnational knowledge networks: studying longterm effects of academic mobility to Germany, 1954-2000. Global Networks 9: 315-338.

Jöns H. 2011. Centre of calculation. In The SAGE Handbook of Geographical Knowledge, Agnew JA, Livingstone DN (eds.); Sage: London; 158-170. 
Jöns H, Hoyler M. 2013. Global geographies of higher education: the perspective of world university rankings. Geoforum 46: 45-59.

Jöns H, Mavroudi E, Heffernan M. 2014. Mobilizing the elective diaspora: US-German academic exchanges since 1945. Transactions of the Institute of British Geographers DOI: 10.1111/tran.12062

King R. 2012. Geography and migration studies: retrospect and prospect. Population, Space and Place 18: 134-153.

King R, Ruiz-Gelices E. 2003. International student migration and the European 'year abroad': effects on European identity and subsequent migration behaviour. International Journal of Population Geography 9: 229-252.

King R, Skeldon R 2010. 'Mind the gap!' Integrating approaches to internal and international migration. Journal of Ethnic and Migration Studies 36: 1619-1646.

Koser K, Salt J. 1997. The geography of highly skilled international migration. International Journal of Population Geography 3: 285-303.

Krohn C-D, Von Zur Mühlen P, Paul G, Winckler L (eds.). 1998. Handbuch der deutschsprachigen Emigration 1933-45. Wissenschaftliche Buchgesellschaft: Darmstadt.

Latour B. 1987. Science in Action: How to Follow Scientists and Engineers through Society. Harvard University Press: Cambridge, MA.

Law J. 2002. Objects and spaces. Theory, Culture \& Society 19: 91-103.

Legg S. 2005. Foucault's population geographies: classifications, biopolitics and governmental spaces. Population, Space and Place 11: 137-156. 
Leung M. 2011. Of corridors and chains: translocal developmental impacts of academic mobility between China and Germany. International Development Planning Review 33: 475-489.

Leung MWH. 2013. 'Read ten thousand books, walk ten thousand miles': geographical mobility and capital accumulation among Chinese scholars. Transactions of the Institute of British Geographers 38: 311-324.

Leydesdorff L, Wagner CS. 2009. Is the United States losing ground in science? A global perspective on the world science system. Scientometrics 78: 23-36. Livingstone, DN. 2003. Putting Science in its Place: Geographies of Scientific Knowledge. The University of Chicago Press: Chicago

Lowell LB, Findlay A. 2001. Migration of Highly Skilled Persons from Developing Countries: Impact and Policy Responses: Synthesis Report. International Labour Office: Geneva.

NSB (ed.). 2014. Science and Engineering Indicators 2014. National Science Board: Arlington, VA. http://www.nsf.gov/statistics/indicators/ (accessed $12^{\text {th }}$ July 2014).

OECD (ed.). 2013. OECD Science, Technology and Industry Scoreboard 2013: Innovation for Growth. OECD: Paris.

Olds K. 2007. Global assemblage: Singapore, foreign universities, and the construction of a 'global education hub'. World Development 35, 959-975.

Paasi A. 2005. Globalisation, academic capitalism, and the uneven geographies of international journal publishing spaces. Environment and Planning A 37: 769789. 
Parmar I. 2002. American foundations and the development of international knowledge networks. Global Networks 2: 13-30.

Pietsch T. 2010. Wandering scholars? Academic mobility and the British world, 18501940. Journal of Historical Geography 36: 377-387.

Sadlak S, Liu NC (eds.). 2007. The World-Class University and Ranking: Aiming Beyond Status. UNESCO-CEPES: Bucharest.

Salt J. 1997. International Movements of the Highly Skilled. OECD: Paris.

Saxenian A. 2006. The New Argonauts: Regional Advantage in a Global Economy. Harvard University Press: Cambridge, MA.

ShanghaiRanking Consultancy (ed.). 2013. Academic Ranking of World Universities. http://www.arwu.org (accessed $12^{\text {th }}$ July 2014)

Simões A, Carneiro A, Diogo MP (eds.). 2003. Travels of Learning: A Geography of Science in Europe. Springer: Dordrecht.

Smith DP, King R. 2012. Editorial introduction: Re-making migration theory. Population, Space and Place 18: 127-133.

Smith MP, Favell A (eds.). 2006. The Human Face of Global Mobility: International Highly Skilled Migration in Europe, North America and the Asia-Pacific. Transaction Publishers: New Brunswick, NJ.

Solimano A. 2008. Causes and consequences of talent mobility. In The International Mobility of Talent: Types, Causes, and Development Impact, Solimano A (ed.); Oxford University Press: Oxford, 1-18.

Taylor PJ. 1996. The Way the Modern World Works: World Hegemony to World Impasse. John Wiley: Chichester. 
Taylor PJ, Hoyler, M, Evans DM. 2008. A geohistorical study of 'the rise of modern science': mapping scientific practice through urban networks. Minerva 46: 391410.

Urry J. 2007. Mobilities. Polity Press: Cambridge.

Vom Brocke B. 1981. Der deutsch-amerikanische Professorenaustausch: Preußische Wissenschaftspolitik, internationale Wissenschaftsbeziehungen und die Anfänge einer deutschen auswärtigen Kulturpolitik vor dem Ersten Weltkrieg. Zeitschrift für Kulturaustausch 31: 128-181

Waters JL. 2012. Geographies of international education: mobilities and the reproduction of social (dis)advantage. Geography Compass 6: 123-136.

Weingart P. 1998. Wissenschaft und Forschung. In Handwörterbuch zur Gesellschaft Deutschlands, Schäfers B, Zapf W (eds.); Leske and Budrich: Opladen; 720-731.

Welch A. 2008. Myths and modes of mobility: The changing face of academic mobility in the global era. In Students, Staff and Academic Mobility in Higher Education, Byram M, Dervin F (ed.); Cambridge Scholars Publishing: Newcastle; 292-311. Yang R, Welch AR. 2010. Globalisation, transnational academic mobility and the Chinese knowledge diaspora: an Australian case study. Discourse: Studies in the Cultural Politics of Education 31: 593-607.

Zweig D, Fung CS, Han D. 2008. Redefining the brain drain: China's 'diaspora option'. Science, Technology and Society 13: 1-33. 
Figures

Figure 1. Talent mobility as mobilisation processes in centres of calculation.

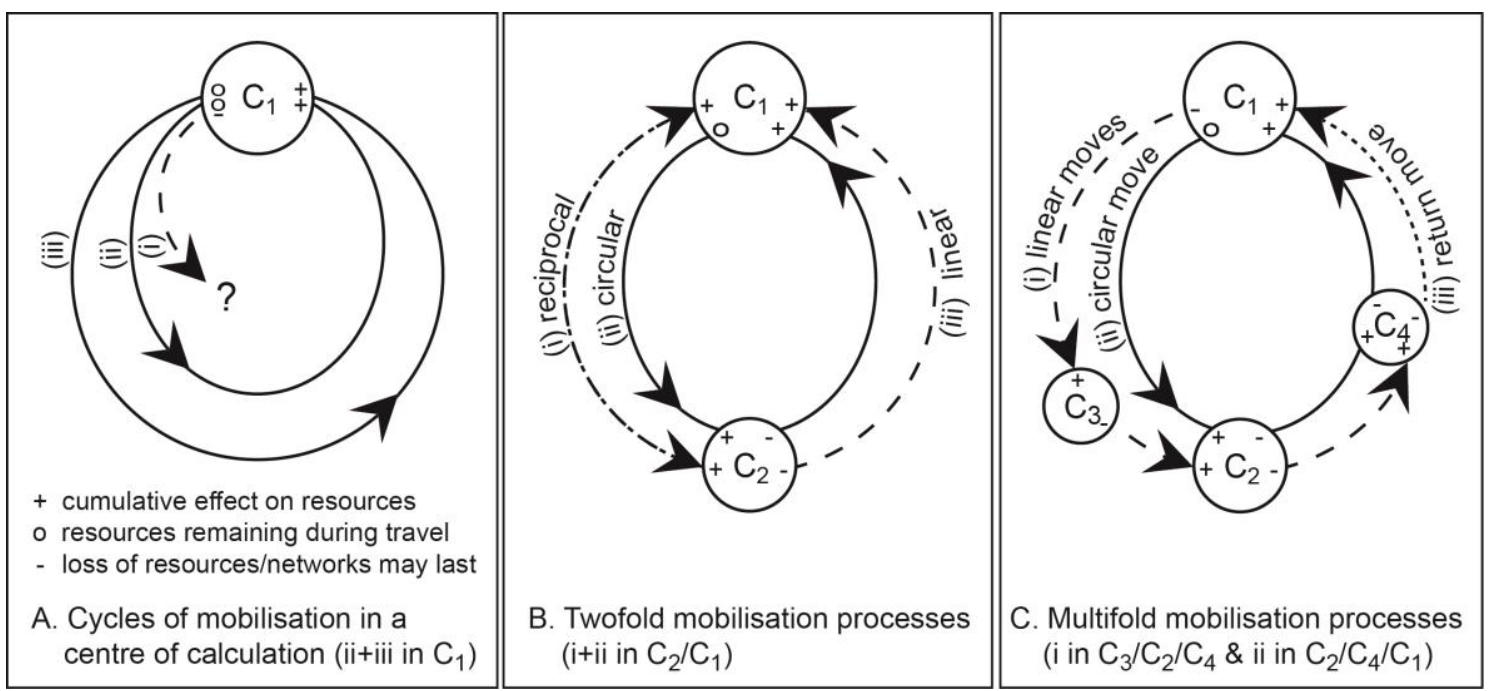

Source: a. adapted from Latour (1987: 220); b. \& c. own design. 
Figure 2. Development of overseas academic leaves by Cambridge academics, 1901$1955(N=739)$.

\begin{tabular}{|c|c|c|}
\hline 300 & $100 \%$ & $100 \%$ \\
\hline & $90 \%$ & $90 \%$ \\
\hline & & \\
\hline 200 & $70 \%-$ & $70 \%$ \\
\hline 150 & $50 \%-$ & $50 \%$ \\
\hline 100 & $40 \%+$ & $40 \%$ \\
\hline 501 & $20 \%$ & $20 \%$ \\
\hline & $10 \%-$ & $10 \%$ \\
\hline 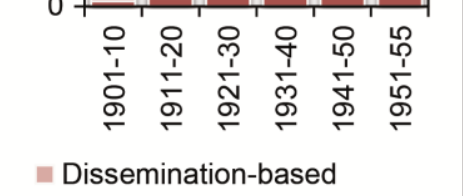 & 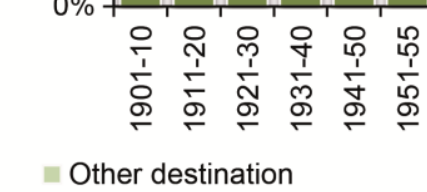 & 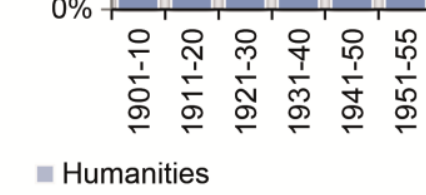 \\
\hline Research-based & British Empire & - Social Sciences \\
\hline & = Europe & Engineering Sciences \\
\hline & ॥ United States & = Natural Sciences \\
\hline A. By number and type of work & B. By destination & C. By discipline \\
\hline
\end{tabular}

Sources: CUA, GB, Min III.1 to Min III.7 and GB, Boxes 301 to 308. 
Figure 3. Destinations of research-based overseas academic leaves by Cambridge academics, 1901-1955.

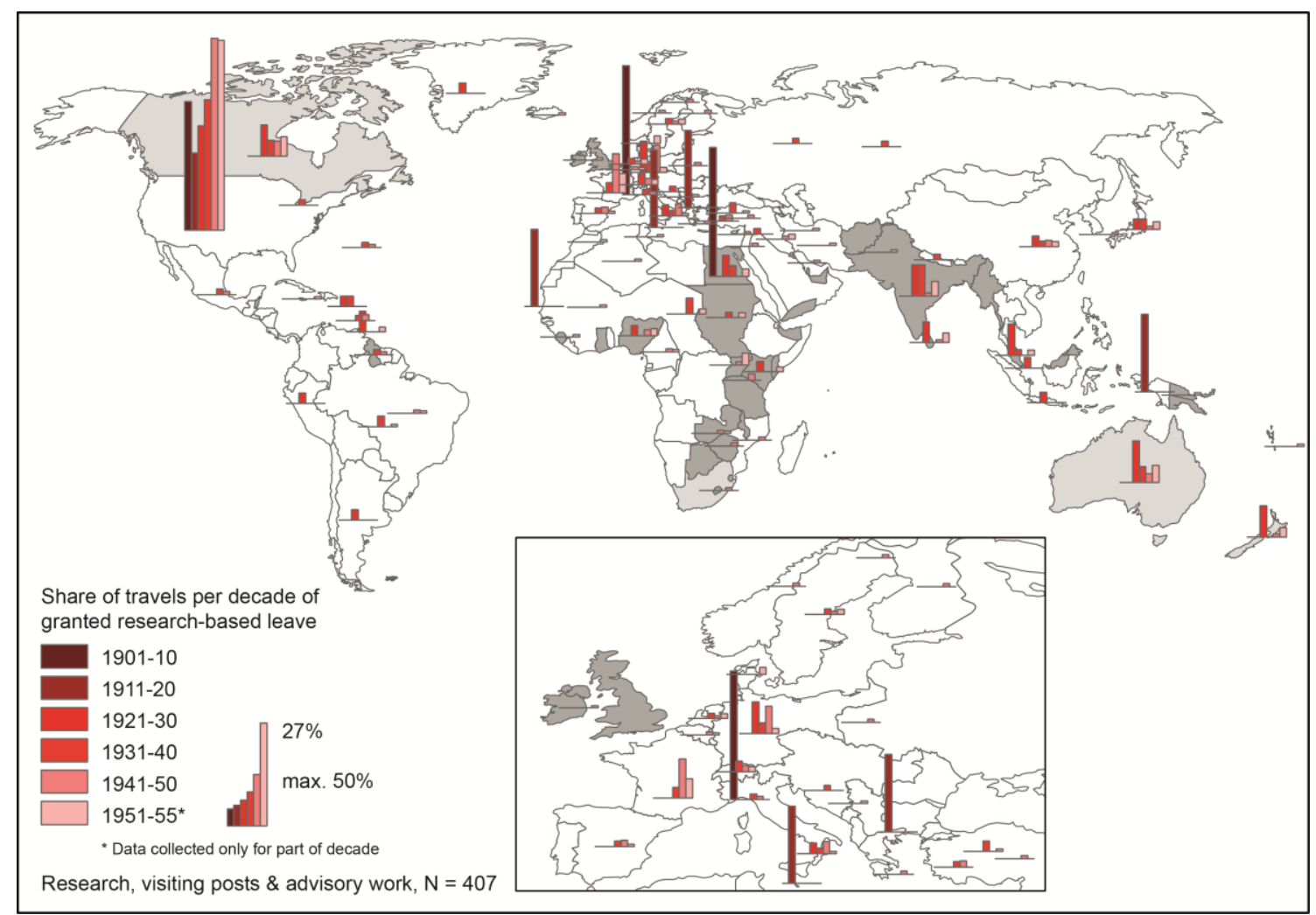

Sources: CUA, GB, Min III.1 to Min III.7 and GB, Boxes 301 to 308 . 
Figure 4. Destinations of dissemination-based overseas academic leaves by Cambridge academics, 1901-1955.

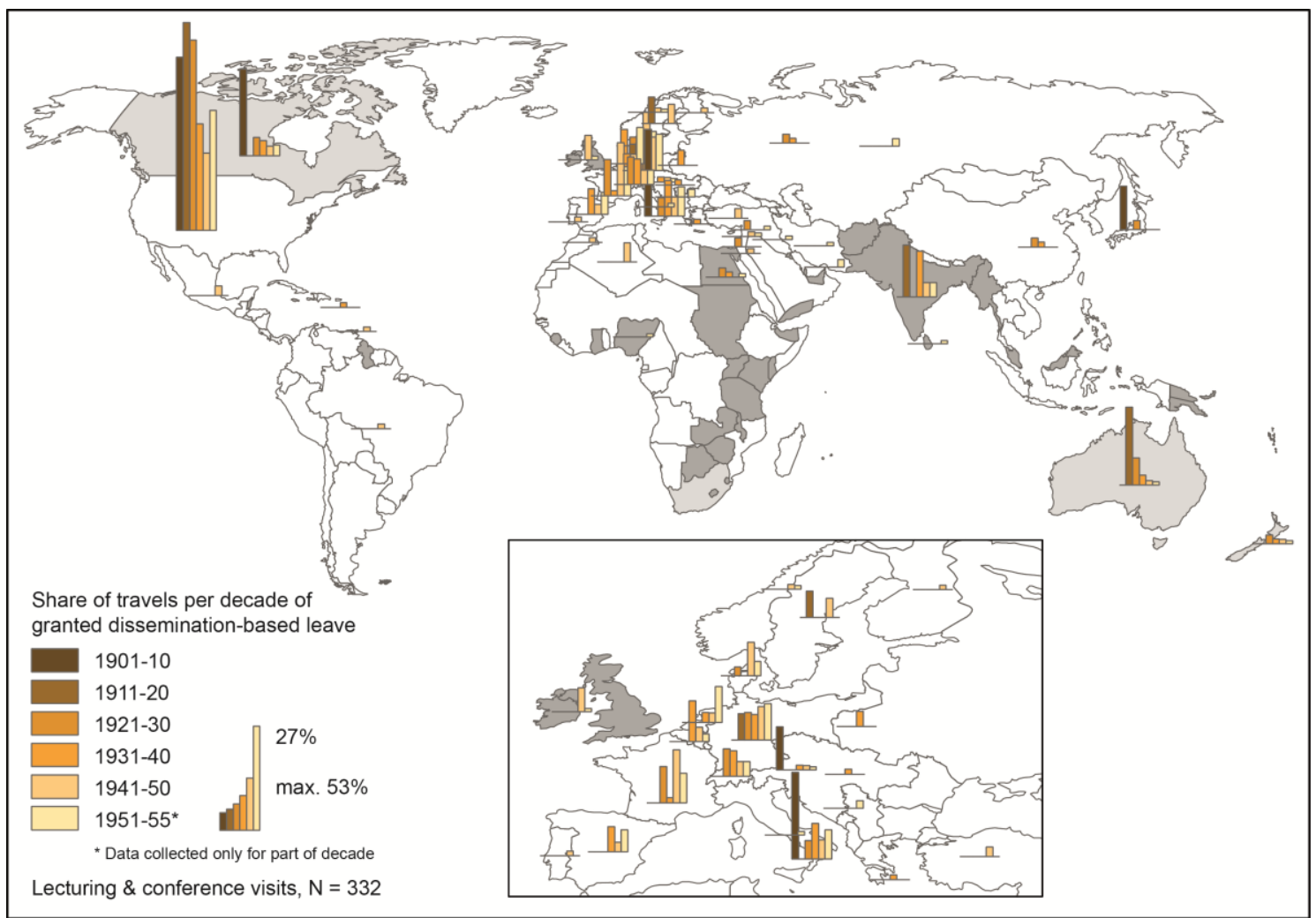

Sources: CUA, GB, Min III.1 to Min III.7 and GB, Boxes 301 to 308 . 
Figure 5. Development of Humboldt research fellowships in the Federal Republic of Germany, $1954-2010$ ( $N=21,686)$.

\begin{tabular}{|c|c|c|}
\hline $18000-$ & $100 \%$ & $100 \%$ \\
\hline 16000 & $90 \%$ & $90 \%$ \\
\hline 14000 & $80 \%$ & $80 \%$ \\
\hline 12000 & $70 \%$ & $70 \%$ \\
\hline 10000 & $60 \%$ & $60 \%$ \\
\hline 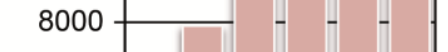 & $40 \%-$ & $40 \%$ \\
\hline $6000 t$ & $30 \%$ & $30 \%$ \\
\hline $4000 t$ & $20 \%$ & $20 \%$ \\
\hline 2000 & $10 \%$ & $10 \%$ \\
\hline 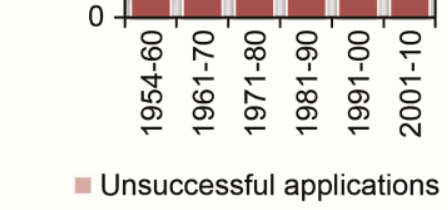 & 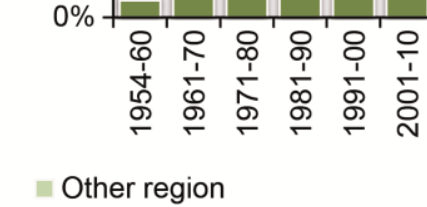 & 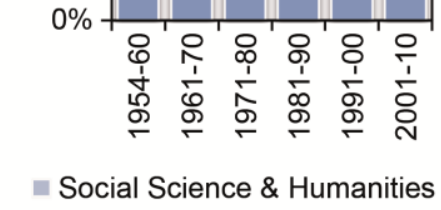 \\
\hline - Successful applications & $=$ Asia & Engineering Sciences \\
\hline & $\begin{array}{l}\text { Europe } \\
\text { = United States \& Canada }\end{array}$ & - Natural Sciences \\
\hline A. By number and success & B. By global region of origin & C. By discipline \\
\hline
\end{tabular}

Sources: Database and published annual reports of the Humboldt Foundation. 
Figure 6. Source countries of Humboldt research fellows in the Federal Republic of Germany, 1954-2010.

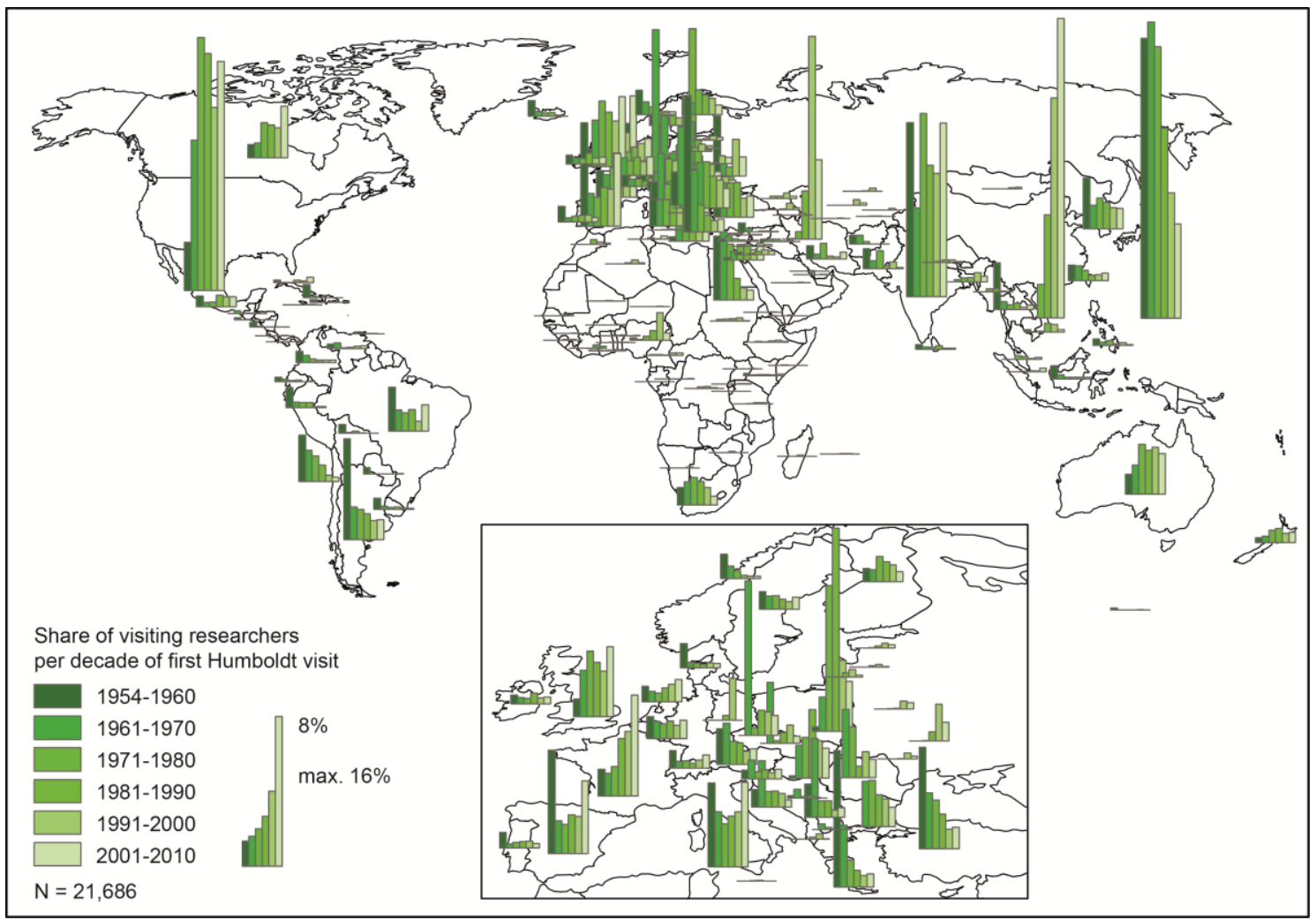

Sources: Database and published annual reports of the Humboldt Foundation. 